\title{
Post-Transcriptional Regulation of Synaptic Vesicle Protein Expression and the Developmental Control of Synaptic Vesicle Formation
}

\author{
Christopher Daly and Edward B. Ziff \\ Department of Biochemistry, Howard Hughes Medical Institute, New York University Medical Center, New York, \\ New York 10016
}

The regulated expression of synaptic vesicle (SV) proteins during development and the assembly of these proteins into functional SVs are critical aspects of nervous system maturation. We have examined the expression patterns of four SV proteins in embryonic hippocampal neurons developing in culture and have found that increases in the levels of these proteins result primarily from post-transcriptional regulation. Synaptotagmin I, vamp 2 , and synapsin I proteins are synthesized at nearly constant rates as the neurons develop. However, these proteins are relatively unstable at early times in culture and undergo a progressive increase in half-life with time, possibly as a result of an increase in the efficiency with which they are incorporated into SVs. In contrast, synaptophysin is synthesized at a very low rate at early times in culture, and its rate of synthesis increases dramatically with time. The increase in synaptophysin synthesis is not simply the result of an increase in mRNA level, but is largely attributable to an increase in the rate of translational initiation. Despite the nearly constant rates of synthesis of synaptotagmin I, vamp 2, and synapsin I, we show that the number of SVs in these developing neurons increases, and that SV proteins are more efficiently targeted to SVs at later times in culture. Our results suggest that SV production during development is not limited by the rates of transcription of genes encoding the component proteins, thus allowing control of this process by cytoplasmic mechanisms, without signaling to the nucleus.

Key words: synaptic vesicle proteins; protein half-life; translational initiation; synaptic vesicle formation; hippocampal neurons; neuronal differentiation
Synaptic transmission requires the assembly of functional synaptic vesicles $(\mathrm{SVs})$ in presynaptic nerve terminals. Thus, the regulated expression of the protein components of SVs, and the relationship between this regulation and the control of SV formation, are critical aspects of nervous system development. Several detailed analyses have described the pattern of expression of SV proteins and their corresponding mRNAs during development. Synapsin I mRNA is detectable relatively early in development, by embryonic days 12-14 (Melloni and DeGennaro, 1994), and its level increases at times of synapse formation in several brain regions (Haas and DeGennaro, 1988; Haas et al., 1990; Zurmohle et al., 1994). Synaptophysin mRNA is also expressed early in development (Bergmann et al., 1991; Mahata et al., 1993; Marazzi and Buckley, 1993), and synaptophysin protein levels increase during periods of synapse formation (Devoto and Barnstable, 1989; Leclerc et al., 1989). Levels of other SV proteins, including synaptotagmin and synaptophysin II, also increase during synaptogenesis (Lou and Bixby, 1993, 1995). Thus, it is clear that SV proteins are expressed well before functional synapses appear, and that their expression increases at times of synapse formation.

\footnotetext{
Received Dec. 11, 1996; revised Jan. 17, 1997; accepted Jan. 24, 1997.

We thank R. Scheller and T. Sudhof for plasmids and P. DeCamilli, R. Jahn, L. Reichardt, and T. Sudhof for antibodies. We are grateful to Adam Boxer for advice on culturing hippocampal neurons, and to Pavel Osten and Robert Schneider for critical reading of this manuscript. C.D. is an Associate and E.B.Z. an Investigator of the Howard Hughes Medical Institute.

Correspondence should be addressed to Edward B. Ziff, Department of Biochemistry, Howard Hughes Medical Institute, New York University Medical Center, 550 First Avenue, New York, NY 10016.

Copyright (C) 1997 Society for Neuroscience $\quad 0270-6474 / 97 / 172365-11 \$ 05.00 / 0$
}

However, the molecular mechanisms underlying this regulation remain uncharacterized.

Studies of cultured neurons confirm that expression of SV proteins is a relatively early event in neuronal development. In primary cultures of dissociated hippocampal neurons, SV proteins are present before neurite outgrowth (Fletcher et al., 1991), and isolated axons contain clusters of synaptic vesicles (Fletcher et al., 1991; Matteoli et al., 1992; Kraszewski et al., 1995). In addition, studies of cultured neurons have supported the notion that the initial basal level of expression of these proteins is modulated during synapse formation (Fletcher et al., 1991; Tixier-Vidal et al., 1992). The mechanisms that regulate SV protein expression during development appear to be complex. There are several cases in which there is a discordance between the patterns of mRNA expression and protein expression (Bergmann et al., 1991; Lou and Bixby, 1993; Melloni et al., 1994), suggesting that posttranscriptional mechanisms may be involved.

In this study, we use dissociated cultures of embryonic rat hippocampal neurons to investigate the molecular mechanisms underlying the developmental regulation of SV protein expression and to relate these mechanisms to the control of SV formation. We have found that synaptotagmin I, vamp 2, and synapsin I proteins are synthesized at nearly constant rates, but exhibit progressive increases in half-life, as these neurons develop. In contrast, synaptophysin expression is controlled by an increase in the rate of mRNA translation. Despite the absence of significant increases in the rates of synthesis of synaptotagmin I, vamp 2, and synapsin I, the number of SVs increases dramatically with time in culture. Our findings suggest that production of SVs during development is not limited by the rates of transcription of genes 
encoding SV components, and may therefore be controlled primarily by cytoplasmic mechanisms, without signaling to the nucleus.

\section{MATERIALS AND METHODS}

Cell culture. Hippocampi were dissected from embryonic day 18 rats and dissociated by treatment with $0.25 \%$ trypsin $\left(15 \mathrm{~min}, 37^{\circ} \mathrm{C}\right)$ followed by trituration in a fire-polished Pasteur pipette. Cells were plated onto tissue culture dishes coated with $0.1 \mathrm{mg} / \mathrm{ml}$ poly-L-lysine at a density of 350-400 cells $/ \mathrm{mm}^{2}$. The cells were plated in MEM containing Earle's salts and glutamine supplemented with $10 \%$ fetal bovine serum, $0.45 \%$ glucose, 1 mM pyruvate, $25 \mu \mathrm{M}$ glutamate, $50 \mathrm{U} / \mathrm{ml}$ penicillin, and $50 \mu \mathrm{g} / \mathrm{ml}$ streptomycin. After 3-4 hr, when cells had become adherent, the plating medium was replaced with Neurobasal medium containing B27 serumfree supplement, $0.5 \mathrm{~mm}$ glutamine, and antibiotics. Approximately onethird of the medium was exchanged every $4 \mathrm{~d}$. Under these conditions, the cultures are essentially free of glia (Brewer et al., 1993). All media, as well as B27 supplement, were obtained from Life Technologies (Grand Island, NY).

Western blot. Hippocampal neurons were lysed in $1 \times$ SDS gel loading buffer $(50 \mathrm{~mm}$ Tris, $\mathrm{pH}$ 6.8, $0.1 \mathrm{~m}$ dithiothreitol, $2 \% \mathrm{SDS}$, and $10 \%$ glycerol). Protein was resolved on SDS polyacrylamide gels and transferred to nitrocellulose. Membranes were blocked in 5\% nonfat dry milk in Tris-buffered saline(TBS) $/ 0.1 \%$ Tween 20 . After incubation with the primary antibody (in blocking solution), membranes were washed 3 times with TBS/Tween $20(0.1-0.5 \%)$, incubated with peroxidase-conjugated secondary antibody from Amersham (Arlington Heights, IL), and again washed 3 times with TBS/Tween 20. Proteins were visualized using enhanced chemiluminescence detection reagents (Amersham). The following antibodies were used in Western blots: purified polyclonal serum against synapsin I from Chemicon (Temecula, CA), polyclonal serum against rat synaptotagmin I (gift of T. Sudhof, University of Texas Southwestern Medical Center, Dallas, TX) (Perin et al., 1990), monoclonal antibody against rat synaptophysin (gift of R. Jahn, Yale University School of Medicine, New Haven, CT) (Sudhof et al., 1987b), monoclonal antibody against rat vamp 2 (gift of R. Jahn) (Edelmann et al., 1995), monoclonal antibody against rat syntaxin $1 \mathrm{~A}$ from Sigma (St. Louis, MO), and monoclonal antibody against glyceraldehyde phosphate dehydrogenase (Chemicon).

RNase protection assay. To generate antisense RNA probes, fragments of the cloned rat synaptophysin cDNA (gift of T. Sudhof) (Sudhof et al., 1987a), rat vamp 2 cDNA (gift of R. Scheller, Stanford University School of Medicine, Palo Alto, CA) (Elferink et al., 1989), and rat synaptotagmin I cDNA (gift of R. Scheller) (Perin et al., 1990) were amplified using PCR. A fragment of the rat synapsin I cDNA (Sudhof et al., 1989) was amplified from total rat brain cDNA. PCR reactions used primers containing EcoRI or BamHI restriction sites to allow cloning of the PCR products into the multiple cloning sequence of the $\mathrm{pGem}-3 \mathrm{Z}$ vector from Promega (Madison, WI). The construct used to generate a probe for $18 \mathrm{~S}$ rRNA was obtained from Ambion (Austin, TX). Radiolabeled antisense RNA probes were generated by transcribing the linearized templates using SP6 or T7 RNA polymerase in the presence of $\left[\alpha^{-32} \mathrm{P}\right]$ GTP $(800$ $\mathrm{Ci} / \mathrm{mmol}$ ) from DuPont NEN (Boston, MA). The radiolabeled probes were hybridized to total RNA that had been isolated from hippocampal neurons by guanidinium thiocyanate extraction (Chomczynski and Sacchi, 1987). The hybridizations were done in $20 \mu \mathrm{l}$ of $80 \%$ formamide, $40 \mathrm{~mm}$ 1,4-piperazinediethanesulfonic acid, $\mathrm{pH} 6.7,0.4 \mathrm{M} \mathrm{NaCl}$, and $1 \mathrm{~mm}$ EDTA. After overnight hybridization, samples were treated with $30 \mathrm{U} / \mathrm{ml}$ T2 RNase for $60 \mathrm{~min}$ at $30^{\circ} \mathrm{C}$ in $0.3 \mathrm{ml}$ of $50 \mathrm{~mm}$ sodium acetate, $2 \mathrm{~mm}$ EDTA, $0.1 \mathrm{M} \mathrm{NaCl}$ to digest the unprotected probe. Protected probe fragments were ethanol-precipitated and resolved on 6 or $8 \%$ denaturing polyacrylamide gels.

Metabolic labeling. Hippocampal neurons were washed once with methionine/cysteine (met/cys)-free DMEM (Life Technologies) and then incubated in this medium for $15 \mathrm{~min}$. The medium was then removed and replaced with met/cys-free DMEM containing $\left[{ }^{35} \mathrm{~S}\right] \mathrm{met} / \mathrm{cys}(1000 \mathrm{Ci} /$ mmol) express protein labeling mix (DuPont NEN). For experiments assessing the rate of synthesis of SV proteins, cells cultured for 1,4 , or $8 \mathrm{~d}$ were labeled for $15 \mathrm{~min}$ with $0.4 \mathrm{mCi}$ of label and then lysed. Aliquots of each lysate, containing equal numbers of trichloroacetic acid (TCA)precipitable counts, were then used in immunoprecipitations. For pulsechase experiments, cells cultured for 1,3 , or $8 \mathrm{~d}$ were labeled for $30 \mathrm{~min}$ with $0.1 \mathrm{mCi}$ of $\left[{ }^{35} \mathrm{~S}\right] \mathrm{met} / \mathrm{cys}$. Cells were then washed with Neurobasal/ B27 and fed with Neurobasal/B27 without label (the conditioned medium that the cells had been in at the time of the experiment). Cells were lysed after the appropriate chase time, and aliquots of lysate were used in immunoprecipitations. If there were any minor differences in the overall rates of degradation of cellular proteins at different days in culture, the differences were adjusted for so that at each chase time, the aliquots of lysate from 1,3 , and $8 \mathrm{~d}$ cultured cells contained the same fraction of the total counts incorporated into protein during the labeling period. In Figure 6 , the aliquots of lysate used to immunoprecipitate synaptophysin from 1 and $3 \mathrm{~d}$ cultures contained approximately 8 and 3.5 times more TCA-precipitable counts, respectively, than the lysate from $8 \mathrm{~d}$ cultures. These adjustments were necessary because of the very low rate of synaptophysin synthesis at early times in culture.

Immunoprecipitations. Hippocampal neurons labeled with $\left[{ }^{35} \mathrm{~S}\right] \mathrm{met} / \mathrm{cys}$ were scraped into lysis buffer [1\% Nonidet P-40 (NP40), $0.2 \%$ deoxycholate, $0.15 \mathrm{M} \mathrm{NaCl}$, and $50 \mathrm{~mm}$ Tris, $\mathrm{pH} 8.0$ ] containing $1 \mu \mathrm{g} / \mathrm{ml}$ leupeptin, $1 \mu \mathrm{g} / \mathrm{ml}$ pepstatin, and $100 \mu \mathrm{g} / \mathrm{ml}$ phenylmethylsulfonyl fluoride (PMSF). Cells were lysed by rocking in a microfuge tube for $20 \mathrm{~min}$ at $4^{\circ} \mathrm{C}$. Lysates were precleared with an appropriate control antibody and protein A/G-agarose beads from Santa Cruz Biotechnology (Santa Cruz, CA). Precleared lysates were incubated with antibody for $1-2 \mathrm{hr}$ on ice. Immunoglobulin was collected by incubating with protein $\mathrm{A} / \mathrm{G}$-agarose beads for $1 \mathrm{hr}$ at $4^{\circ} \mathrm{C}$, rocking. In general, immunoprecipitates were washed as follows: once with lysis buffer; twice with $0.2 \%$ NP40, $10 \mathrm{~mm}$ Tris, $\mathrm{pH} 7.5,0.15 \mathrm{M} \mathrm{NaCl}$, and 2 mм EDTA; twice with $0.2 \%$ NP40, 10 mM Tris, pH 7.5, $0.5 \mathrm{M} \mathrm{NaCl}$, and $2 \mathrm{~mm}$ EDTA; and once with $10 \mathrm{~mm}$ Tris, $\mathrm{pH}$ 7.5. Synapsin I immunoprecipitates were washed with RIPA buffer $(0.15 \mathrm{~m} \mathrm{NaCl}, 50 \mathrm{~mm}$ Tris, $\mathrm{pH} 8.0,0.1 \%$ SDS, $0.5 \%$ deoxycholate, and $1 \%$ NP40). Proteins were recovered by boiling the beads in SDS gel loading buffer and then resolved on SDS polyacrylamide gels. The following antibodies were used in the immunoprecipitations: a purified polyclonal serum against synapsin I (Chemicon), a monoclonal antibody (SY38) against rat synaptophysin from Boehringer Mannheim (Indianapolis, IN), a monoclonal antibody against rat vamp 2 (gift of R. Jahn) (Edelmann et al., 1995), and a monoclonal antibody against rat synaptotagmin I (gift of L. Reichardt, University of California, San Francisco, CA) (Matthew et al., 1981).

Polysome fractionation. Hippocampal neurons were scraped into lysis buffer (20 mM HEPES, pH 6.8, $0.1 \mathrm{M} \mathrm{KCl}, 10 \mathrm{~mm} \mathrm{MgCl}_{2}$, and $0.5 \% \mathrm{NP} 40$ ) containing $0.1 \mathrm{mg} / \mathrm{ml}$ cycloheximide and $200 \mathrm{U} / \mathrm{ml}$ RNasin (Promega). Nuclei were pelleted by centrifugation, and the cytoplasmic extract was layered on top of an $11 \mathrm{ml}$ sucrose gradient $(0.5-1.5 \mathrm{M})$ and spun at 36,000 rpm for $110 \mathrm{~min}$ at $4^{\circ} \mathrm{C}$ in an SW41 rotor. The gradient was prepared in lysis buffer without detergent or cycloheximide. After centrifugation, fractions of $1 \mathrm{ml}$ were collected by hand from the top of the gradient and diluted into $1 \mathrm{ml}$ of diethylpyrocarbonate (DEPC)-treated $\mathrm{H}_{2} \mathrm{O}$ containing $0.6 \%$ SDS, 2 mm EDTA, and $30 \mu \mathrm{g}$ of yeast RNA as carrier. Fractions were extracted twice with equal volumes of phenol and chloroform/ isoamyl alcohol (24:1) and then extracted once with chloroform/isoamyl alcohol. RNA was then ethanol-precipitated, washed with $70 \%$ ethanol, and resuspended in DEPC-treated $\mathrm{H}_{2} \mathrm{O}$. RNA from the gradient fractions was then used in RNase protection assays with probes for synaptophysin, synapsin I, and vamp 2, as described above.

Isolation of synaptic vesicles. Synaptic vesicles were isolated from cultured hippocampal neurons as described for PC12 cells (Grote et al., 1995). Hippocampal neurons cultured for 1 or $8 \mathrm{~d}$ were douncehomogenized in $0.15 \mathrm{M} \mathrm{NaCl}, 10 \mathrm{~mm}$ HEPES, $\mathrm{pH} 7.3,0.1 \mathrm{~mm} \mathrm{MgCl}_{2}$, and $1 \mathrm{~mm}$ EGTA containing leupeptin, pepstatin, and PMSF. The number of cells used at each time point was chosen so that each homogenate would contain equal amounts of total protein. After homogenization, nuclei were pelleted by centrifugation at $1000 \times g$ for $5 \mathrm{~min}$ at $4^{\circ} \mathrm{C}$. An aliquot of each postnuclear supernatant was set aside to allow comparison of total cellular SV protein levels. The postnuclear supernatant was then centrifuged at $10,000 \times g$ for $15 \mathrm{~min}$ at $4^{\circ} \mathrm{C}$. The supernatant from this spin was applied to a $4.6 \mathrm{ml} 5-25 \%$ glycerol gradient on a $0.4 \mathrm{ml}$ cushion of $50 \%$ sucrose. Both the gradient and the sucrose cushion were prepared in homogenization buffer. The gradients were centrifuged at 55,000 rpm for $46 \mathrm{~min}$ in an SW55 rotor. Fractions of $0.35 \mathrm{ml}$ were collected by hand from the top of the gradient, and proteins were precipitated with acetone. Proteins from the gradient fractions were then analyzed by Western blot as described above. Synaptic vesicles are found approximately in the middle of the gradient (fractions 6-8 from the top) (Grote et al., 1995). 

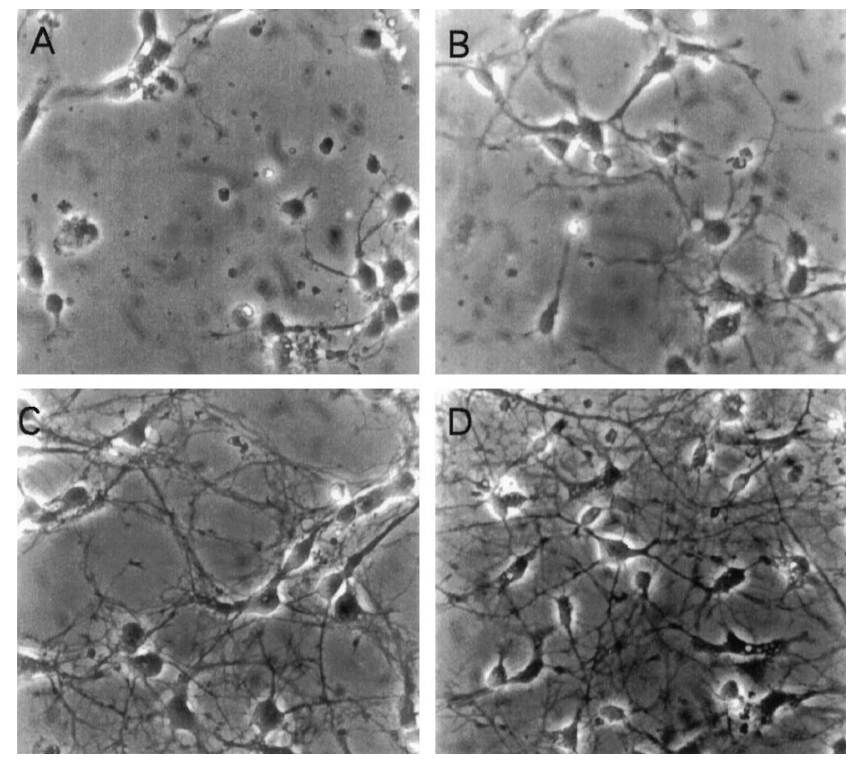

Figure 1. Morphological development of dissociated hippocampal neurons from embryonic day 18 rats. Photomicrographs of neurons cultured for $1(A), 3(B), 6(C)$, or $9(D)$ d. Cultures were maintained on poly-Llysine-coated dishes as described in Materials and Methods.

\section{RESULTS}

\section{Expression of synaptic vesicle proteins is controlled post-transcriptionally}

To investigate the developmental regulation of synaptic vesicle protein expression, we used dissociated cultures of rat embryonic day 18 hippocampal neurons (Banker and Cowan, 1977). This cell culture system has been widely used to study many aspects of neuronal differentiation and function, including responses to neurotrophins (Collazo et al., 1992; Ip et al., 1993), changes in gene expression in response to depolarization (Zafra et al., 1990), and formation of synapses (Basarsky et al., 1994; Fletcher et al., 1994). After plating, these cells undergo a well defined program of differentiation that includes neurite extension, establishment of neuronal polarity, and synapse formation (Dotti et al., 1988). As shown in Figure 1, the initially round cells begin to extend neurites within $1 \mathrm{~d}$ of plating, and by $6 \mathrm{~d}$ after plating have established a dense neuritic network.

To study the expression pattern of SV proteins during this period of neuronal development, we prepared whole-cell lysates from cells that had been in culture for 1, 3, 5, 7, or $9 \mathrm{~d}$. Equal amounts of total protein from each lysate were analyzed by Western blot to determine the levels of synapsin I, synaptotagmin I, synaptophysin, and vamp 2 . As shown in Figure $2 A$, there is a large increase in the levels of all of these proteins between 1 and $9 \mathrm{~d}$ in culture. When normalized to the levels of glyceraldehyde phosphate dehydrogenase (GAPDH), the levels of the SV proteins increase five- to sevenfold. In contrast, expression of syntaxin $1 \mathrm{~A}$, a protein that is localized predominantly to the axonal plasma membrane, remains nearly constant over this same time period (Fig. 2A). The difference in regulation between synaptophysin and syntaxin $1 \mathrm{~A}$ is graphed in Figure $2 B$ and is significant because it indicates a specific increase of SV proteins, and not simply a general increase of proteins involved in neurotransmitter release. It is important to note that the increase in SV proteins shown in Figure 2 is relative to total cell protein. Thus, although the total
A

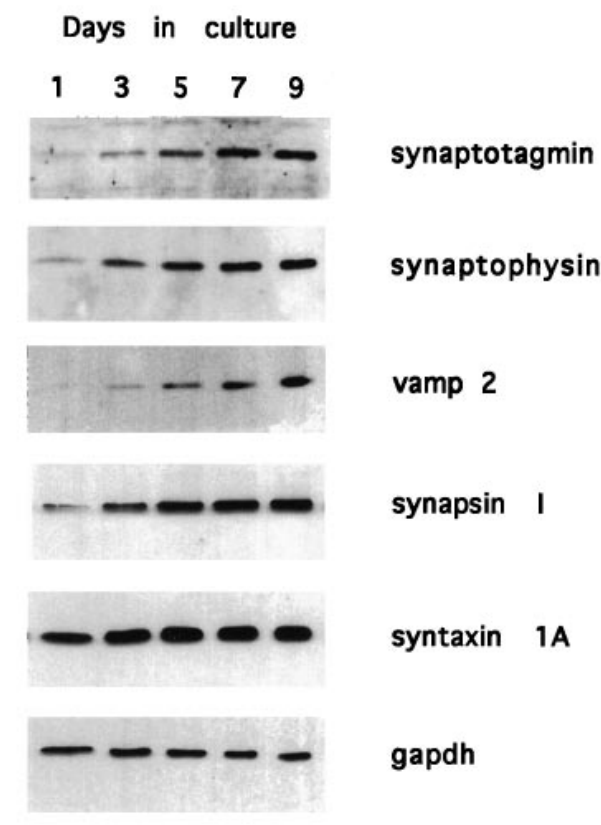

\section{B}

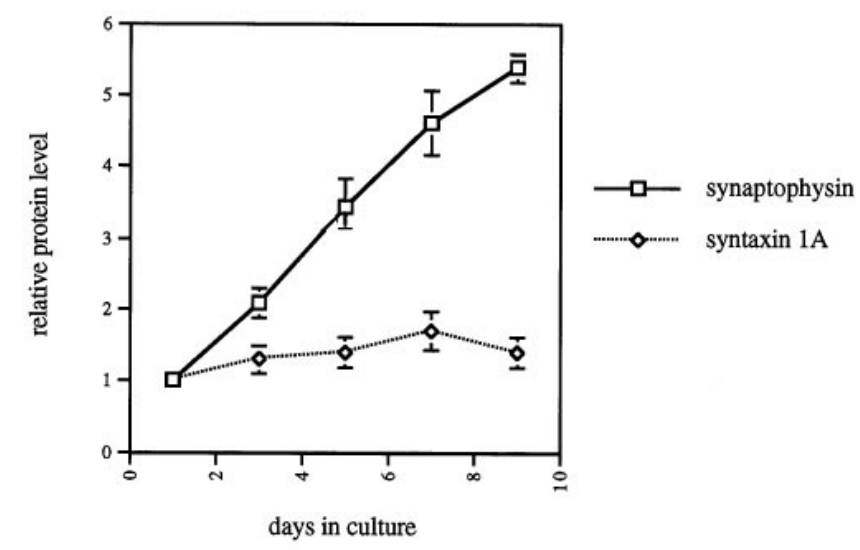

Figure 2. Steady-state levels of synaptic vesicle proteins increase in developing hippocampal neurons. $A$, Whole-cell lysates were prepared from neurons cultured for 1, 3, 5, 7, or $9 \mathrm{~d}$. Equal amounts of total protein from each lysate were resolved on $8-12 \%$ SDS polyacrylamide gels and transferred to nitrocellulose. Membranes were then probed with the indicated antibodies, as described in Materials and Methods. The synapsin I signal represents both synapsin Ia and synapsin $\mathrm{Ib}$, which migrated as a single species. $B$, Signals from Western blots like those shown in $A$ were quantitated using National Institutes of Health Image software. Relative levels of synaptophysin and syntaxin $1 \mathrm{~A}$ protein are plotted against days in culture. The signals from the $1 \mathrm{~d}$ culture are given a value of 1.0. All values are normalized against GAPDH levels. Data points represent mean \pm SEM for three to five experiments.

protein content per cell increases four- to fivefold between 1 and $9 \mathrm{~d}$ in culture (data not shown), the levels of SV proteins are selectively increased relative to this general increase. During this period, the amount of SV proteins per cell goes up 20-25-fold, whereas the level of syntaxin 1A goes up four- to fivefold (data not shown). The increase in syntaxin $1 \mathrm{~A}$ protein per cell can thus be viewed as a result of the general increase in the rate of protein biosynthesis that takes place in these neurons as they extend neurites and become larger. The fact that SV protein levels are 
A

Days in culture

138

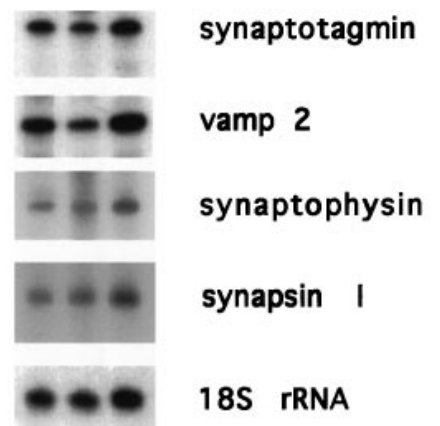

B

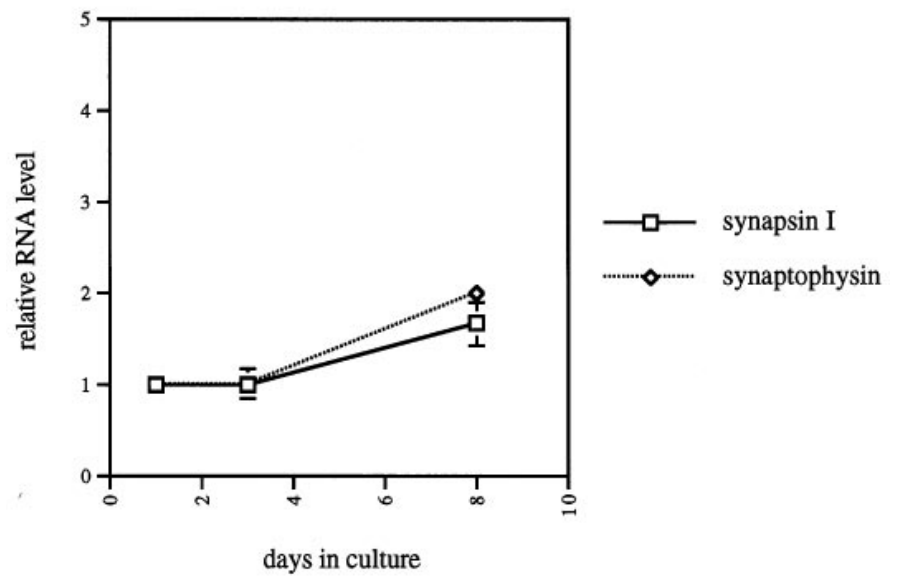

Figure 3. Steady-state levels of RNAs encoding synaptic vesicle proteins are nearly constant in developing hippocampal neurons. $A$, Total RNA was isolated from neurons cultured for 1, 3, or $8 \mathrm{~d}$. Equal amounts of total RNA from each time point were hybridized with the indicated ${ }^{32} \mathrm{P}$-labeled antisense RNA probes as described in Materials and Methods. After hybridization, samples were digested with T2 RNase, and protected probe fragments were resolved on $6-8 \%$ denaturing polyacrylamide gels. The synapsin I signal represents both synapsin Ia and synapsin Ib, because the antisense probe is protected by both of these mRNAs. $B$, Signals from RNase protection assays like those shown in $A$ were quantitated. Relative levels of synaptophysin and synapsin I RNA are plotted against days in culture. The signals from the $1 \mathrm{~d}$ culture are given a value of 1.0. All values are normalized against $18 \mathrm{~S}$ rRNA levels. Data points represent mean \pm SEM for three experiments.

selectively increased indicates that they are subject to some form of specialized control, which cannot be viewed as a simple component of neuronal growth.

The simplest explanation for the increase in SV protein levels was an increase in the rates of transcription of the corresponding genes. To test this, steady-state RNA levels of synapsin I, synaptotagmin I, synaptophysin, and vamp 2 were measured by RNase protection assay. Total RNA was isolated from neurons that had been in culture for 1,3 , or $8 \mathrm{~d}$, and equal amounts of RNA from each time point were used in the assay. As shown in Figure $3 A$, there was no increase in any of the RNAs between 1 and $3 \mathrm{~d}$ in culture. By $8 \mathrm{~d}$ in culture, the level of all of these RNAs had increased modestly, with the increases ranging from 1.7-fold (synapsin I) to 2-fold (synaptophysin), all normalized to levels of $18 \mathrm{~S}$
rRNA (Fig. 3A,B). None of the increases in RNA level is sufficient to account for the increase in the level of the corresponding protein. Therefore, we conclude that the regulation of SV protein expression during differentiation of hippocampal neurons is primarily post-transcriptional, and must occur at the level of translation or protein half-life.

\section{The rate of translational initiation on the synaptophysin mRNA is regulated developmentally}

To investigate the possibility that expression of one or more of the $\mathrm{SV}$ proteins is regulated translationally, we assessed the rate of incorporation of $\left[{ }^{35} \mathrm{~S}\right] \mathrm{met} / \mathrm{cys}$ into the SV proteins as a function of time in culture. Cells cultured for 1,4 , or $8 \mathrm{~d}$ were given a $15 \mathrm{~min}$ pulse of $\left[{ }^{35} \mathrm{~S}\right] \mathrm{met} / \mathrm{cys}$. After the pulse, the cells were lysed, and the relative rates of translation of synapsin I, synaptotagmin I, synaptophysin, and vamp 2 were determined by immunoprecipitating these proteins from aliquots of lysate containing equal numbers of TCA-precipitable counts. Thus, our assay reveals the rates of synthesis of SV proteins relative to total cellular protein synthesis.
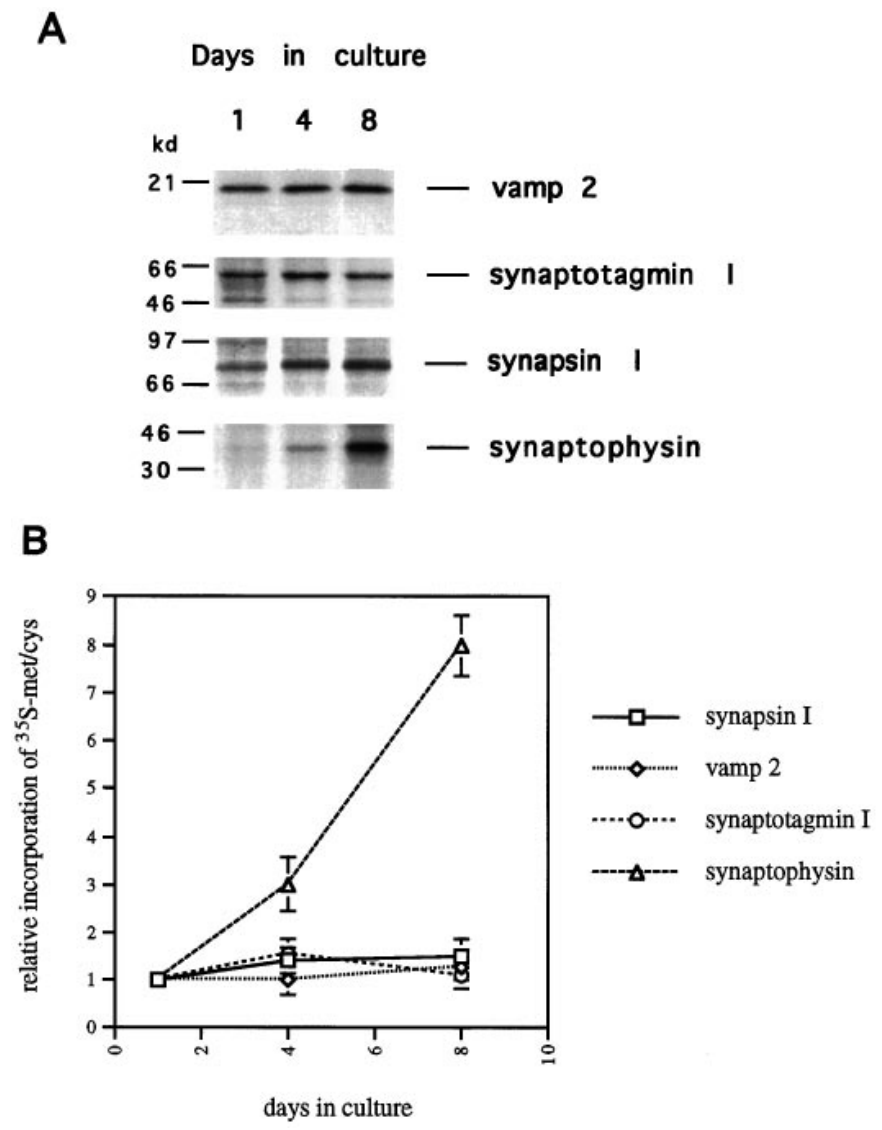

Figure 4. The rate of synthesis of synaptophysin increases in developing hippocampal neurons. $A$, Hippocampal neurons cultured for 1,4 , or $8 \mathrm{~d}$ were labeled for $15 \mathrm{~min}$ with $0.4 \mathrm{mCi}$ of $\left[{ }^{35} \mathrm{~S}\right] \mathrm{met} / \mathrm{cys}$. Cell lysates were prepared and subjected to immunoprecipitation with the indicated antibodies, as described in Materials and Methods. Immunoprecipitations were performed with equal numbers of TCA-precipitable counts from each time point. Immunoprecipitates were boiled in SDS gel loading buffer, and recovered proteins were resolved on $8-12 \%$ SDS polyacrylamide gels. $B$, Signals from immunoprecipitations like those shown in $A$ were quantitated. Relative incorporation of label into synaptophysin, synaptotagmin I, vamp 2, and synapsin I is plotted against days in culture. The signals from the $1 \mathrm{~d}$ culture are given a value of 1.0. Data points represent mean \pm SEM for three to five experiments. 
As shown in Figure $4 A$, the rate of incorporation of $\left[{ }^{35} \mathrm{~S}\right] \mathrm{met} / \mathrm{cys}$ into vamp 2 , synaptotagmin I, and synapsin I was nearly constant from 1 to $8 \mathrm{~d}$. These results are consistent with those of Figure 3, which showed only minor changes in the levels of the RNAs encoding these proteins. It should be noted that the absolute rate of synthesis of these proteins per cell does increase with time in culture, but this increase is simply a result of the increase in the overall rate of protein synthesis that takes place in these neurons as they become larger (data not shown). In contrast, the rate of incorporation of $\left[{ }^{35} \mathrm{~S}\right] \mathrm{met} / \mathrm{cys}$ into synaptophysin increased dramatically during this same period (Fig. $4 A$ ). Thus, the rate of synaptophysin translation, relative to total cellular protein synthesis, is increasing with time in culture. Figure $4 B$ illustrates this, comparing the relative incorporation of $\left[{ }^{35} \mathrm{~S}\right] \mathrm{met} / \mathrm{cys}$ into the various SV proteins as a function of time in culture. Synaptophysin translation rate goes up approximately 8-fold, whereas translation of the other SV proteins increases only 1.5 -fold. The increased rate of synaptophysin translation is not simply the result of an increase in RNA level. As shown in Figure 3, synaptophysin RNA levels do not change at all during the first $3 \mathrm{~d}$ in culture. Thus, the increased rate of incorporation of $\left[{ }^{35} \mathrm{~S}\right] \mathrm{met} / \mathrm{cys}$ into synaptophysin observed between 1 and $4 \mathrm{~d}$ in culture is independent of a change in RNA level. Only at later times, between 4 and $8 \mathrm{~d}$, does an increase in synaptophysin RNA make a contribution to the increase in synaptophysin synthesis. Because the level of synaptophysin RNA increases twofold between 1 and $8 \mathrm{~d}$ in culture (Fig. 3), whereas the rate of synthesis of synaptophysin increases eightfold (Fig. 4), we estimate that the specific increase in synaptophysin translation (the increase in incorporation of $\left[{ }^{35} \mathrm{~S}\right] \mathrm{met} / \mathrm{cys}$ into synaptophysin protein per mRNA molecule) is approximately fourfold. The large increase in the rate of synaptophysin synthesis between 1 and $8 \mathrm{~d}$, combined with the nearly constant rate of synthesis of the other SV proteins, results in a dramatic change in the relative amounts of the various SV proteins being produced (Fig. 4). This result indicates that the molecular mechanisms controlling synaptophysin expression are distinct from those controlling expression of the other SV proteins. Although the synaptotagmin I, vamp 2, and synapsin I mRNAs are efficiently translated at early times in culture, efficient translation of the synaptophysin mRNA appears to require an additional level of neuronal maturation.

An increase in the rate of incorporation of $\left[{ }^{35} \mathrm{~S}\right] \mathrm{met} / \mathrm{cys}$ into synaptophysin protein, without a corresponding increase in the level of synaptophysin mRNA, could be achieved by an increase in the rate of translation initiation or by an increase in the rate of peptide chain elongation. In the vast majority of cases of regulated translation, initiation is the regulated step (Hershey, 1991). An increase in the rate of initiation, accompanied by a constant elongation rate, will result in a greater number of ribosomes being associated with an mRNA, whereas an increase in elongation rate, accompanied by a constant rate of initiation, will result in the association of fewer ribosomes. Fractionation of polysomes on a sucrose gradient can distinguish between these possibilities. The position to which an mRNA sediments in the gradient is a function of the number of ribosomes associated with its coding sequence. Therefore, we analyzed sedimentation of polysomes to determine the mode of regulation of synaptophysin translation. Cytoplasmic extracts were prepared from neurons cultured for 1 or $8 \mathrm{~d}$. The extracts were fractionated on $0.5-1.5 \mathrm{M}$ sucrose gradients. Fractions were collected from the top of the tubes (fraction 1), and mRNA was isolated from each fraction. The mRNA was then subjected to RNase protection assay using probes for synaptophysin, synapsin I, and vamp 2. Figure $5 A$ illustrates the results from such an experiment. Vamp 2 mRNA, which has a coding region of approximately 350 nucleotides, sediments mainly in fraction 6 at both 1 and $8 \mathrm{~d}$ in culture. Synapsin I mRNA, which has a larger coding region (approximately 2100 nucleotides), sediments farther down in the gradients, mainly in fraction 8 at both times (Fig. $5 A$ ). The fact that the vamp 2 and synapsin I mRNAs do not undergo a shift in their polysome profiles between 1 and $8 \mathrm{~d}$ in culture indicates that the number of ribosomes associated with these mRNAs does not vary as a function of the developmental state of the neurons. This is consistent with the results shown in Figures 3 and 4, which demonstrate that these proteins are synthesized at rates proportional to the levels of the mRNAs encoding them, which are nearly constant between 1 and $8 \mathrm{~d}$. In contrast, the position to which the synaptophysin mRNA sediments varies with time in culture (Fig. $5 A$ ). At $1 \mathrm{~d}$ in culture, synaptophysin mRNA, which has a coding sequence of approximately 900 nucleotides, sediments primarily in fraction 7 . However, at $8 \mathrm{~d}$ in culture, synaptophysin mRNA sediments mainly in fraction 8 . Thus, at $8 \mathrm{~d}$ in culture, synaptophysin mRNA molecules are associated with a greater number of ribosomes than at $1 \mathrm{~d}$ in culture, indicating an increase in the rate of translational initiation on the synaptophysin mRNA. These results are graphed in Figure 5B, which clearly shows the difference in sedimentation of the synaptophysin mRNA at 1 versus $8 \mathrm{~d}$, in contrast to the identical sedimentation of the vamp 2 and synapsin I mRNAs. The results of four such experiments for the synaptophysin mRNA are summarized in Figure $5 C$, which illustrates the shift in polysome profile between 1 and $8 \mathrm{~d}$ in culture. The majority (59\%) of the synaptophysin mRNA isolated from $1 \mathrm{~d}$ cultures sediments in fractions 5-7, whereas only $40 \%$ sediments in fractions $8-10$, in which larger polysomes are found. In contrast, only $17 \%$ of the synaptophysin mRNA isolated from 8 d cultures sediments in fractions 5-7, whereas $79 \%$ sediments in fractions $8-10$. Based on the positions to which the vamp 2 and synapsin I mRNAs sediment in the gradients, and the number of ribosomes that can theoretically associate with protein coding sequences of their size (Hershey, 1991), we estimate that at $1 \mathrm{~d}$ in culture, the synaptophysin mRNA is associated with approximately one-half the number of ribosomes as it is at $8 \mathrm{~d}$ in culture. The contention that the shift of synaptophysin mRNA one fraction in the gradient (from fraction 7 to fraction 8 ) is significant is supported by the fact that at $8 \mathrm{~d}$ in culture, the synaptophysin and synapsin I mRNAs sediment to almost the same positions (within one-half of a fraction of each other, Fig. 5A). This is despite the fact that the synapsin I coding sequence can theoretically accommodate approximately 2.5 times more ribosomes than the synaptophysin mRNA. This suggests that at this portion of the gradient, differences of one fraction can be indicative of significant differences in polysome size. Because we cannot state with certainty exactly how many additional ribosomes are associated with the synaptophysin mRNA at later times in culture, it is difficult to establish whether the observed change in ribosome density is, by itself, sufficient to account for the fourfold increase in the specific rate of translation. We cannot rule out an accompanying increase in elongation rate, which would contribute to the increased rate of synthesis. Nevertheless, our data demonstrate that the rate of translational initiation on the synaptophysin mRNA increases in developing hippocampal neurons. 
A

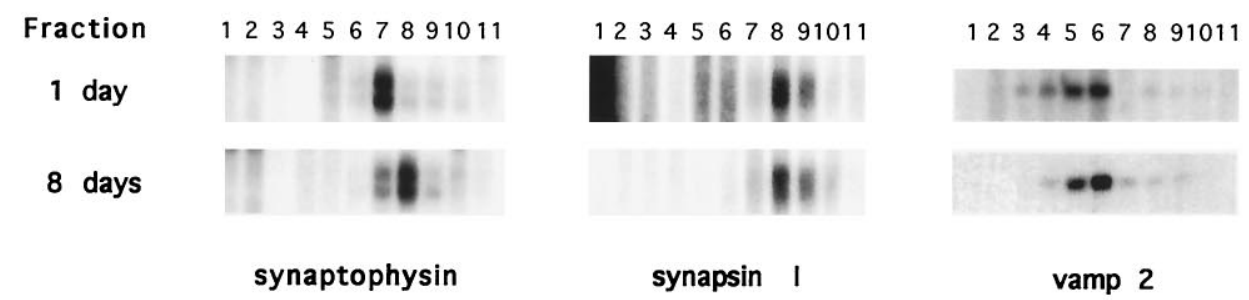

B
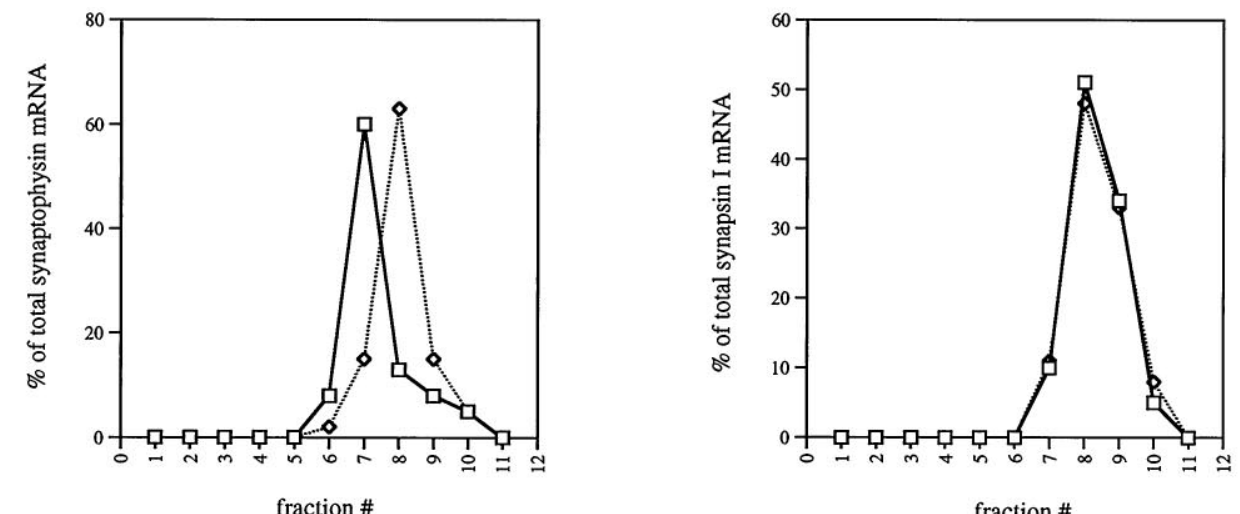

fraction \#

Figure 5. The rate of translational initiation on the synaptophysin mRNA increases in developing hippocampal neurons. $A$, Cytoplasmic extracts were prepared from hippocampal neurons cultured for 1 or $8 \mathrm{~d}$. Extracts were applied to $11 \mathrm{ml}$ of $0.5-1.5 \mathrm{M}$ sucrose gradients and centrifuged for $110 \mathrm{~min}$ at $36,000 \mathrm{rpm}$ in an SW41 rotor. Fractions of $1 \mathrm{ml}$ were collected from the top (fraction 1) of the tubes, and mRNA was extracted from the gradient fractions. The mRNA was then subjected to RNase protection assay with probes against synaptophysin, synapsin I, or vamp 2 as described in Materials and Methods. $B$, The results from the RNase protection assays shown in $A$ were quantitated. Each data point represents the percentage of the total mRNA signal from all 11 fractions that is present in that particular fraction. $C$, The percentage of synaptophysin mRNA, isolated from 1 or $8 \mathrm{~d}$ cultures, sedimenting in fractions 5-7 or 8-10 in experiments identical to that shown in $A$ is graphed. Bars represent mean \pm SEM for four experiments.
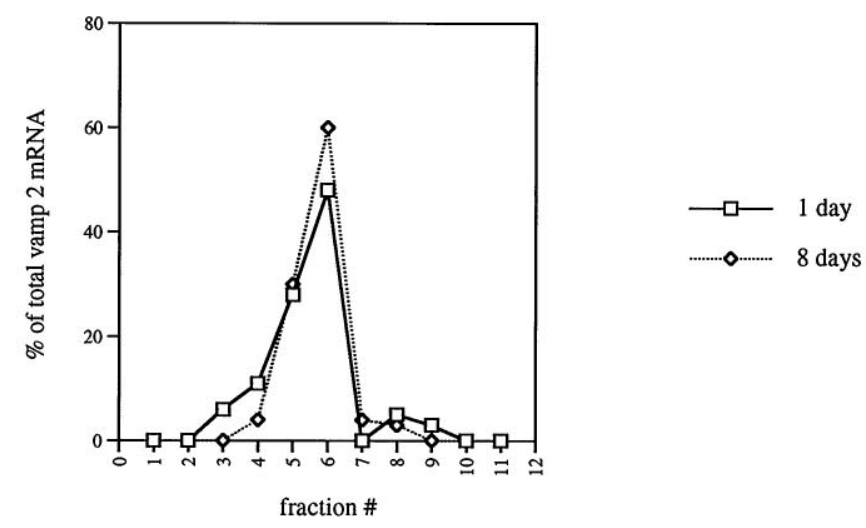

C

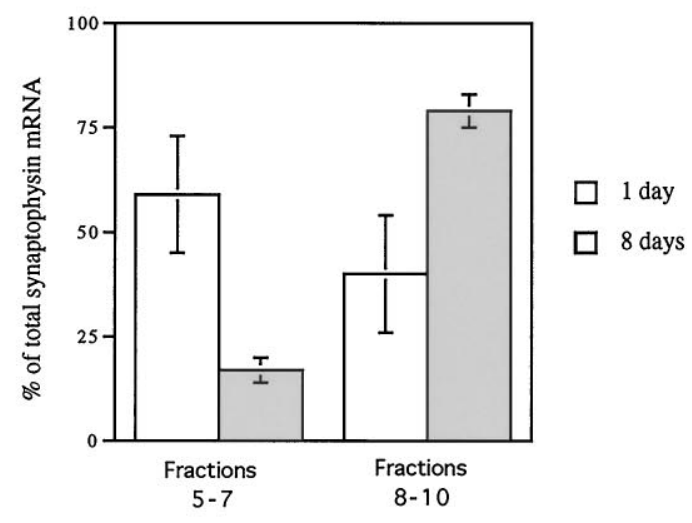

Synapsin I, synaptotagmin I, and vamp 2 levels are regulated by increases in protein half-life

Because we were unable to see significant changes in the rates of synthesis of synapsin I, synaptotagmin I, and vamp 2 during the development of hippocampal neurons (Fig. 4A), we investigated the possibility that the levels of these proteins are regulated by changes in half-life. Cells cultured for 1,3 , or $8 \mathrm{~d}$ were labeled with $\left[{ }^{35}\right.$ S $]$ met/cys, and then incubated for various times in the absence of label. After the indicated chase times, cell lysates were prepared, and synapsin I, synaptotagmin I, vamp 2, and synaptophysin proteins were immunoprecipitated (Fig. $6 A$ ). At $1 \mathrm{~d}$ in culture, a significant fraction (at least $50 \%$ ) of the labeled synap- 
A
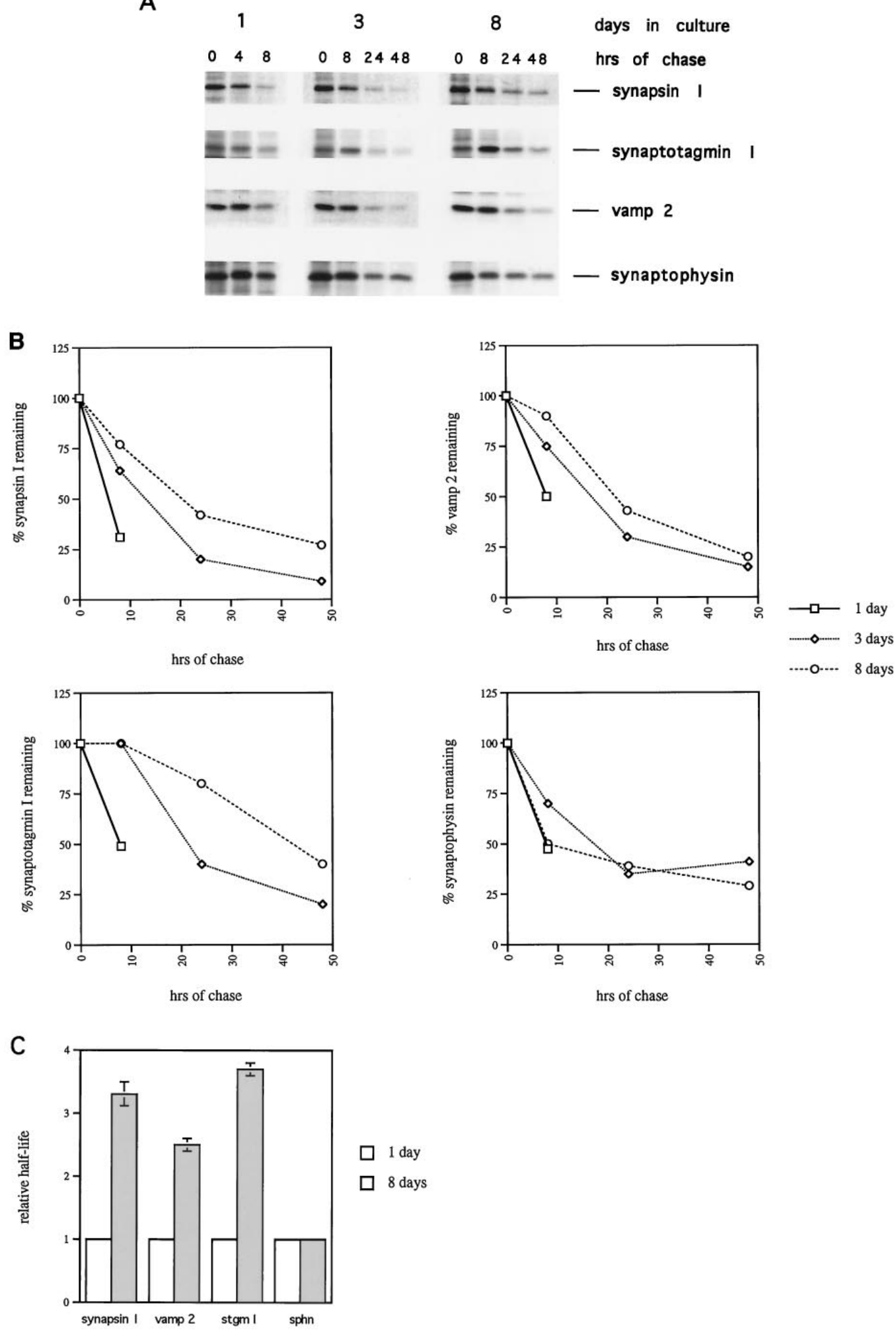

Figure 6. The stability of synapsin I, synaptotagmin I, and vamp 2 increases in developing hippocampal neurons. $A$, Hippocampal neurons cultured for 1,3 , or $8 \mathrm{~d}$ were labeled for $30 \mathrm{~min}$ with $0.1 \mathrm{mCi}$ of $\left[{ }^{35} \mathrm{~S}\right] \mathrm{met} / \mathrm{cys}$. The label was then washed out, and cells were incubated in the absence of label for the indicated chase times. Cell lysates were prepared and subjected to immunoprecipitation with the indicated antibodies, as described in Materials and Methods. Immunoprecipitates were boiled in SDS gel loading buffer, and recovered proteins were resolved on 8-12\% SDS polyacrylamide gels. $B$, The signals from the immunoprecipitations in $A$ were quantitated. The signals from the 0 hr chase times are given a value of $100 \%$. The percentage of each protein remaining, as a function of chase time, is plotted. $C$, The estimated relative half-life of synapsin I, vamp 2, synaptotagmin I (stgm I), and synaptophysin $(s p h n)$ measured after 1 or $8 \mathrm{~d}$ in culture is graphed. The half-life was estimated from graphs like those shown in $B$. The half-life at $1 \mathrm{~d}$ is given a value of 1.0. Bars represent mean \pm SEM for three to five experiments, except for synaptophysin, in which case the data are from the experiment shown in $A$. 
sin I, synaptotagmin I, and vamp 2 had been degraded by $8 \mathrm{hr}$ of chase. However, at 3 and $8 \mathrm{~d}$ in culture, a much smaller fraction $(0-35 \%)$ of these proteins had been degraded by $8 \mathrm{hr}$ of chase (Fig. 6A). At $8 \mathrm{~d}$ in culture, compared with $3 \mathrm{~d}$, there was a greater fraction of these three labeled proteins remaining at 24 and $48 \mathrm{hr}$ of chase. The progressive increase in stability of synapsin I, synaptotagmin I, and vamp 2 is illustrated in Figure $6 B$, which compares the percentage of these proteins remaining at 8,24 , and $48 \mathrm{hr}$ of chase, in cells cultured for 1,3 , or $8 \mathrm{~d}$. We did not observe significant differences in the overall rate of degradation of total cellular protein at different times in culture (data not shown). Thus, our assay reveals the rate of degradation of SV proteins at 1,3 , and $8 \mathrm{~d}$ in culture relative to a constant rate of degradation of total cell protein. In contrast to the other SV proteins, synaptophysin exhibited a nearly uniform rate of degradation at all times in culture (Fig. 6A,B). This is consistent with the fact that the increase in the rate of synaptophysin translation (Fig. 4) is sufficient to account for the increase in steady-state synaptophysin level. The fact that synaptophysin stability does not increase with time in culture emphasizes that the increase in stability of synaptotagmin I, synapsin I, and vamp 2 is highly specific. These data further distinguish the mechanism that leads to accumulation of synaptophysin from that controlling the levels of the other SV proteins. Figure $6 C$ shows that the relative half-lives of synapsin I, synaptotagmin I, and vamp 2 (estimated from graphs like those shown in Fig. 6B) increase 2.5-4-fold between 1 and $8 \mathrm{~d}$ in culture, whereas synaptophysin half-life is invariant. Therefore, we conclude that the regulation of synapsin I, synaptotagmin I, and vamp 2 protein levels in developing hippocampal neurons is primarily at the level of protein stability.

\section{The size of the synaptic vesicle pool is not limited by the rates of synthesis of synaptotagmin I, vamp 2, and synapsin I}

We have demonstrated that the steady-state levels of SV proteins, normalized to total cell protein, increase in our cultures (Fig. 2). It seemed likely that the number of SVs, also taken relative to total cell protein, would increase in parallel with the increase in $\mathrm{SV}$ protein levels. To investigate this, we isolated SVs from cultured hippocampal neurons using a procedure devised for isolating SVs from PC12 cells (Grote et al., 1995). Hippocampal neurons cultured for 1 or $8 \mathrm{~d}$ were dounce-homogenized, and the extracts were fractionated on 5-25\% glycerol gradients. The number of cells analyzed at each time point was chosen so that each homogenate would contain the same amount of total protein. Proteins from the peak SV fractions (and several flanking fractions), plus an aliquot of unfractionated homogenate from each time point, were analyzed by Western blot to allow direct comparison of the increase in total cellular SV protein levels with the increase in SV proteins within the SV pool (i.e., the fold increase in $\mathrm{SV}$ number) (Fig. 7A). In our experiments, the $\mathrm{SV}$ peak is found in fractions 6-8 from the top of the gradient, which is in exact agreement with the sedimentation of SVs from PC12 cells (Grote et al., 1995) and from rat brain (Clift-O'Grady et al., 1990) using this procedure. As shown in Figure $7 A$, the levels of total cellular vamp 2, synaptophysin, and synaptotagmin I increased three- to fivefold between 1 and $8 \mathrm{~d}$ in culture. The number of $\mathrm{SVs}$, reflected by the levels of these proteins in the SV fractions $(6-8)$, increased greatly (Fig. $7 A$ ). To determine the fold increase in SV number, vamp 2 levels in SV fractions at 1 and $8 \mathrm{~d}$ were quantitated in an overexposure $(8 \times)$ of the same Western blot (Fig. $7 A$ ). The overexposure allowed visualization of the vamp 2 signal in the SV fractions at $1 \mathrm{~d}$. This quantitation yielded a value of an 11-fold increase in SV number. Quantitations based on synaptotagmin I and synaptophysin levels gave similar values (data not shown). We have consistently observed, as graphed in Figure $7 B$, that the fold increase in SV number is significantly greater than the fold increase in total cellular SV protein levels. This indicates that at later times in culture, a higher percentage of the total cellular SV proteins is contained in SVs, suggesting an increase in the efficiency with which these proteins are targeted to SVs. The fact that the increase in SV number occurs without significant increases in the rates of synthesis of synaptotagmin I, vamp 2, and synapsin I (Fig. 4) also suggests that these proteins are more efficiently incorporated into SVs as neuronal development proceeds. As is true for the increase in steady-state levels of $\mathrm{SV}$ proteins, the increase in SV number is not simply a result of neuronal growth, because the increase shown is relative to total cell protein. Thus, we conclude that SV number increases with time in culture and that this increase is not limited by the rates of synthesis of synaptotagmin I, vamp 2, and synapsin I.

\section{DISCUSSION}

We have used primary cultures of embryonic hippocampal neurons to examine the mechanisms governing $\mathrm{SV}$ protein expression and the formation of SVs during neuronal development. We show that the level of expression of different SV proteins is controlled by distinct post-transcriptional mechanisms. The level of synaptophysin is controlled primarily by rate of translation, whereas the levels of synaptotagmin I, synapsin I, and vamp 2 are controlled primarily by protein half-life. We have demonstrated that the size of the SV pool, relative to total cell protein, increases as hippocampal neurons develop in culture. Because the increase in size of the SV pool occurs in the absence of significant increases in the rates of synthesis of synaptotagmin I, vamp 2, and synapsin I, production of these proteins does not limit formation of SVs.

Based on these results, a tentative model may be proposed that attempts to relate the mechanisms of regulation of SV protein expression to the control of SV formation (Fig. 8). We have demonstrated that the size of the SV pool increases in developing hippocampal neurons (Fig. 7). The increase in SV number theoretically could be attributable to an increase in the efficiency of SV formation with time in culture or to an increase in stability of SVs. The fact that the stability of synaptophysin, a SV component, does not change with time in culture suggests that the stability of SVs does not change with time in culture. Thus, although we have not directly measured the rate of formation of SVs at different times in culture, our data strongly suggest that the efficiency of SV formation increases as the neurons develop. The increases in the half-life of synaptotagmin I and vamp 2 with time parallel the increase in the size of the SV pool, suggesting that the increased half-life of these proteins is a result of the increased efficiency of $\mathrm{SV}$ formation. An increase in efficiency of SV formation with time in culture would allow a greater percentage of the vamp 2 and synaptotagmin I synthesized to be incorporated into SVs. This hypothesis is directly supported by the fact that, at later times in culture, a higher percentage of the total cellular synaptotagmin I and vamp 2 is localized to SVs (Fig. 7). The fact that the increase in efficiency of SV formation does not require significant increases in the rates of synthesis of synaptotagmin I and vamp 2 suggests that, at early times in culture, these proteins are produced at levels in excess of the amount that can be incorporated into SVs. Possibly, the excess amounts of synaptotagmin I and vamp 2, which do not get incorporated into SVs, are degraded at a rela- 
Figure 7. The size of the synaptic vesicle pool, relative to total cell protein, increases in developing hippocampal neurons. $A$, Hippocampal neurons cultured for 1 or $8 \mathrm{~d}$ were douncehomogenized. After pelleting nuclei with a $1,000 \times g$ spin for $5 \mathrm{~min}$, the postnuclear supernatant was centrifuged at $10,000 \times g$ for $15 \mathrm{~min}$. The supernatant from this spin was applied to a $5-25 \%$ glycerol gradient and spun for $46 \mathrm{~min}$ at 55,000 $\mathrm{rpm}$ in an SW55 rotor. Fractions of $0.35 \mathrm{ml}$ were collected from the top (fraction 1) of the gradients, and proteins were precipitated from the fractions with acetone. Proteins from the peak synaptic vesicle fractions (fractions 6-8) and from several flanking fractions plus aliquots of the unfractionated homogenates were then analyzed by Western blot. The blots were probed with the indicated antibodies. The number of cells analyzed at each time point was chosen so that each homogenate would contain the same amount of total protein. Two exposures of the vamp 2 Western blot are shown. The overexposed film $(8 \times)$ at the bottom allows visualization of vamp 2 protein in the SV pool at $1 \mathrm{~d}$ in culture. $B$, The results shown in $A$ were quantitated. The graph depicts the fold increase in total cellular levels of synaptotagmin I (stgm), vamp 2, and synaptophysin (sphn), and the fold increase in SV number, between 1 and $8 \mathrm{~d}$ in culture. To calculate the fold increase in SV number, the signals from the SV proteins in fractions 6-8 at each time point were quantitated and added together. The sums of the signals from these fractions at each time point were then compared. This quantitation was done using overexposed films, like the one shown for vamp $2(8 \times)$. Quantitations based on the levels of each of the SV proteins gave similar values for the increase in SV number.
A

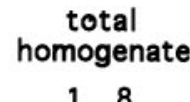

18

synaptophysin

synaptotagmin

vamp 2

vamp $2(8 x)$
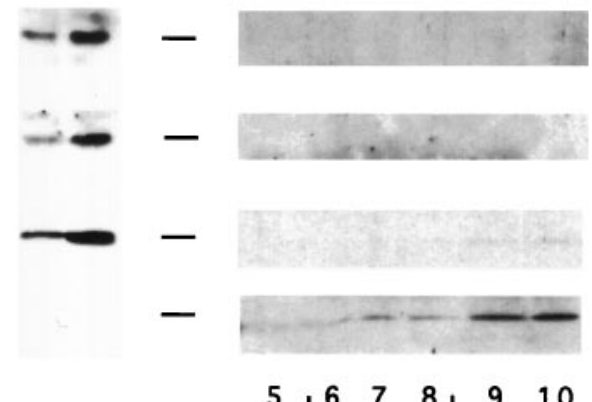

\begin{tabular}{l|lll|ll}
5 & 6 & 7 & 8 & 9 & 10
\end{tabular} fractionated synaptic vesicles 1
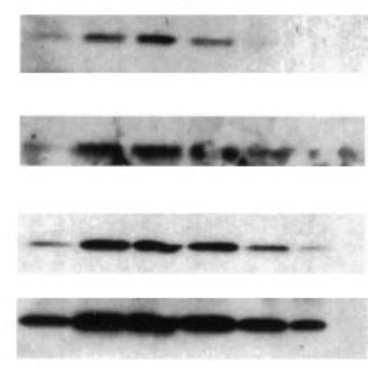

\begin{tabular}{llll|ll}
5 & 6 & 7 & 8 & 9 & 10
\end{tabular}

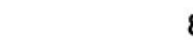

Fraction

B

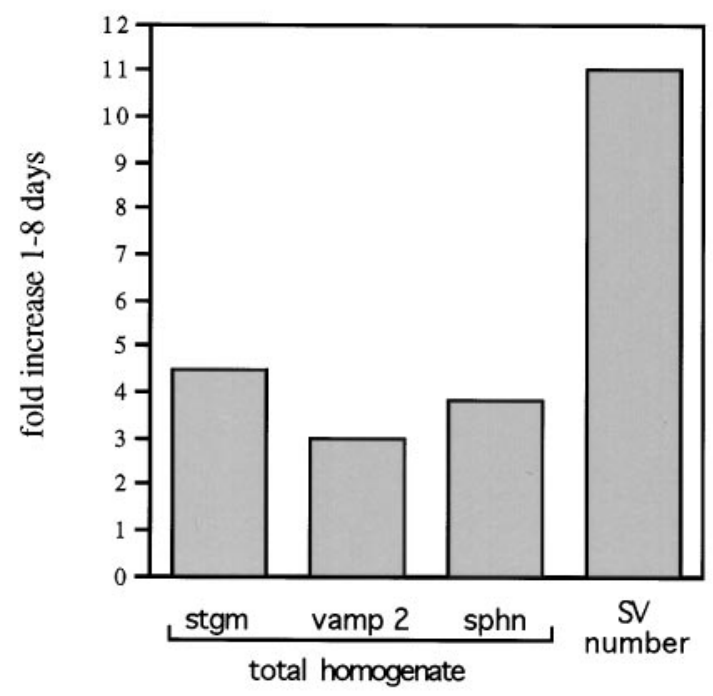

tively high rate. It remains possible that the increase in stability of $\mathrm{SV}$ proteins is not the result of an increase in SV formation, but rather causes the increase in SV formation by increasing the steady-state levels of SV proteins. In this case, the increase in stability of SV proteins would have to be the result of a process unrelated to SV formation. This seems very unlikely because it would require that a process unrelated to SV formation selectively stabilizes SV proteins relative to other membrane proteins.

In a current model of SV biogenesis, SV proteins are transported to the nerve terminal plasma membrane and then endocytosed into early endosomes, where a sorting process separates them from other endosomal proteins allowing mature SVs to bud off (Mundigl and DeCamilli, 1994). Because SVs are not fixed structures and because their membranes are constantly recycling through early endosomes, an increased rate of SV formation from endosomes might allow SV proteins to remain in the SV pool for longer periods of time before they are targeted for degradation. Although very little is known about degradation of SV proteins, it has been shown that integral SV membrane proteins are trans-

ported back to the cell body after fulfilling their function in nerve terminals (Li et al., 1995; Li et al., 1996). Presumably, the retrograde transport of SV proteins allows the vesicles carrying them to fuse with lysosomes in the cell body, resulting in protein degradation (Nixon and Cataldo, 1995). If synaptotagmin I and vamp 2 were not efficiently incorporated into SVs, but instead were accumulating in early endosomes, they might be returned more rapidly to the cell body for degradation.

Our model assumes that the instability of SV proteins at early times in culture is a result of their production in large excess over the rate of SV formation. The invariant half-life of synaptophysin would be explained by the fact that its rate of synthesis is proportional to the rate of SV formation. At early times in culture, when synaptophysin is synthesized at a very low rate, SV formation is inefficient. As the neurons develop, the rate of synaptophysin production increases, with a concomitant increase in the efficiency of SV formation. Inefficient formation of SVs at early times in culture could be attributable to the lack of expression of a protein(s) required for SV formation or to the immature morpholog- 
Figure 8. Diagram outlining the possible relationship between regulation of synaptic vesicle protein expression and the formation of synaptic vesicles. Synaptotagmin I, vamp 2, and synapsin I mRNAs are translated at relatively high rates at early times in culture, but these proteins are unstable. In contrast, synaptophysin mRNA is translated inefficiently at early times in culture. As the neurons develop, the rate of synaptophysin translation increases. In parallel with the increase in synaptophysin expression, the neurons acquire the ability to form SVs more efficiently. Because of the increase in efficiency of SV formation, a higher percentage of the synaptotagmin I and vamp 2 synthesized can be incorporated into SVs, possibly resulting in stabilization of these proteins. The increase in SV number may also cause an increase in synapsin I stability by allowing a greater percentage of the synapsin I synthesized to associate with SVs. The model is described in detail in the Discussion.

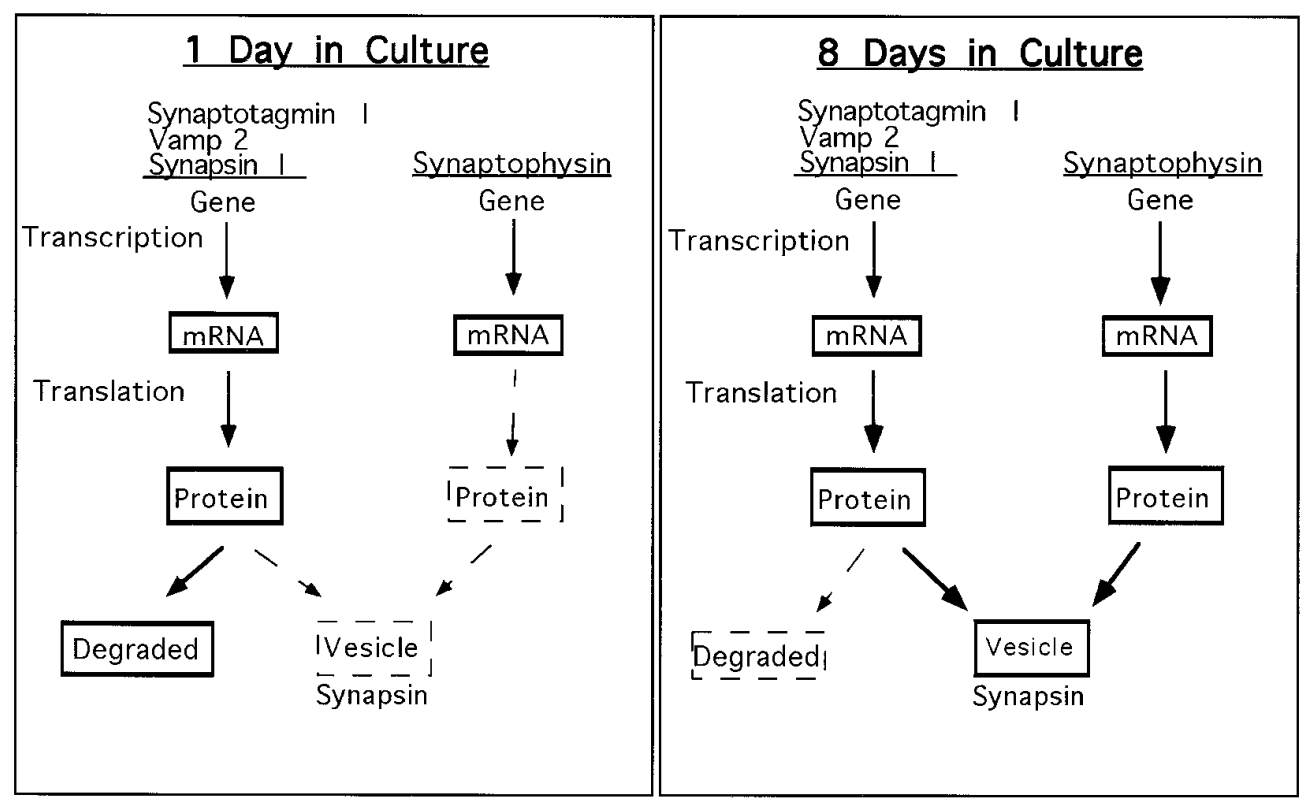

ical state of the neurons, or both. The fact that the efficiency of SV formation is proportional to the rate of synaptophysin synthesis suggests the possibility that synaptophysin plays a role in regulating SV formation. However, at this stage of analysis, only a temporal correlation between the increase in synaptophysin synthesis and the increase in SV formation has been demonstrated. It should be noted that synaptophysin is targeted to SVs more efficiently at $8 \mathrm{~d}$ in culture than it is at $1 \mathrm{~d}$ in culture (Fig. 7). This suggests that synaptophysin level is not the only factor limiting SV formation, at least at $1 \mathrm{~d}$ in culture. Thus, if the increase in synaptophysin expression has a role in regulating SV formation, it is likely to be in cooperation with other changes that take place in these neurons.

Two additional lines of evidence suggest that synaptophysin may play a direct role in SV formation. First, it has been reported that expression of synaptophysin in non-neuroendocrine cells can result in the production of a novel class of cytoplasmic vesicles that are similar in size to SVs (Leube et al., 1989, 1994). The implication is that synaptophysin has the capacity to induce the formation of these vesicles, and by analogy may play some role in SV biogenesis. Second, synaptophysin is found exclusively in SVs (Volknandt et al., 1988; Wiedenmann et al., 1988; Cutler and Cramer, 1990; Walch-Solimena et al., 1993). This is in contrast to several other SV proteins, including synaptotagmin I and vamp 2, which are also found in large, dense-core vesicles (Volknandt et al., 1988; Walch-Solimena et al., 1993; Egger et al., 1994; Papini et al., 1995). It has been suggested that proteins shared between large, dense-core vesicles and SVs may not contain sequences that specifically target them to SVs, but instead are targeted to SVs via interactions with SV-specific proteins, such as synaptophysin, which escort them into SVs (Kelly, 1993). It should be noted that mice that do not express synaptophysin form normal numbers of fully functional SVs (Eshkind and Leube, 1995; McMahon et al., 1996). Thus, the presence of synaptophysin is not an absolute requirement for SV formation. However, a role that synaptophysin normally plays in regulating formation of SVs during development could be fulfilled in the mutant mice by related proteins, such as synaptoporin (Knaus et al., 1990).

Because synapsin I associates with SVs only after they have been formed in nerve terminals (Greengard et al., 1993), an increase in the rate of SV biogenesis would not directly involve synapsin I. However, it is possible that the increase in synapsin I stability observed here is the result of the increased rate of SV formation. If the number of SVs produced was relatively low, and synapsins were present in excess, the excess synapsins that did not associate with SVs might be rapidly degraded. As the rate of SV formation increased, a higher percentage of the synapsin I produced could associate with SVs, possibly resulting in its stabilization. Alternatively, stable expression of synapsin I may be dependent on some structural feature of mature nerve terminals.

In summary, our results indicate that neurons can control the formation of SVs during development without increasing the rates of synthesis of all of the component proteins, but perhaps instead by regulating the synthesis of one or more key proteins. Because the increase in synaptophysin translation parallels the increase in $\mathrm{SV}$ formation, it is possible that synaptophysin is one such protein. In more general terms, our data suggest that $\mathrm{SV}$ formation can be controlled independently of the modulation of transcription of genes encoding SV proteins. This may allow neurons to rapidly increase the production of SVs at a certain point in development without the need for changes in a transcriptional program.

\section{REFERENCES}

Banker GA, Cowan WM (1977) Rat hippocampal neurons in dispersed cell culture. Brain Res 126:397-425.

Basarsky TA, Parpura V, Haydon PG (1994) Hippocampal synaptogenesis in cell culture: developmental time course of synapse formation, calcium influx, and synaptic protein distribution. J Neurosci 14:6402-6411.

Bergmann M, Lahr G, Mayerhoffer A, Gratzl M (1991) Expression of synaptophysin during the prenatal development of the rat spinal cord: correlation with basic differentiation processes of neurons. Neuroscience 42:569-582.

Brewer GJ, Torricelli JR, Evege EK, Price PJ (1993) Optimized survival of hippocampal neurons in B27-supplemented Neurobasal, a new serum-free medium combination. J Neurosci Res 35:567-576.

Chomczynski P, Sacchi N (1987) Single-step method of RNA isolation by acid guanidinium thiocyanate-phenol-chloroform extraction. Anal Biochem 162:156-159.

Clift-O'Grady L, Linstedt AD, Lowe AW, Grote E, Kelly RB (1990) 
Biogenesis of synaptic vesicle-like structures in a pheochromocytoma cell line PC-12. J Cell Biol 110:1693-1703.

Collazo D, Takahashi H, McKay RDG (1992) Cellular targets and trophic functions of neurotrophin-3 in the developing rat hippocampus. Neuron 9:643-656.

Cutler DF, Cramer LP (1990) Sorting during transport to the surface of PC12 cells: divergence of synaptic vesicle and secretory granule proteins. J Cell Biol 110:721-730.

Devoto SH, Barnstable CJ (1989) Expression of the growth cone specific epitope CDA 1 and the synaptic vesicle protein SVP 38 in the developing mammalian cerebral cortex. J Comp Neurol 290:154-168.

Dotti CG, Sullivan CA, Banker GA (1988) The establishment of polarity by hippocampal neurons in culture. J Neurosci 8:1454-1468.

Edelmann L, Hanson PI, Chapman ER, Jahn R (1995) Synaptobrevin binding to synaptophysin: a potential mechanism for controlling the exocytotic fusion machine. EMBO J 14:224-231.

Egger C, Kirchmair R, Kapelari S, Fischer-Colbrie R, Hogue-Angeletti R, Winkler H (1994) Bovine posterior pituitary: presence of p65 (synaptotagmin), PC1, PC2, and secretoneurin in large dense core vesicles. Neuroendocrinology 59:169-175.

Elferink LA, Trimble WS, Scheller RH (1989) Two vesicle-associated membrane protein genes are differentially expressed in the rat central nervous system. J Biol Chem 264:11061-11064.

Eshkind LG, Leube RE (1995) Mice lacking synaptophysin reproduce and form typical synaptic vesicles. Cell Tissue Res 282:423-433.

Fletcher TL, Cameron P, De Camilli P, Banker G (1991) The distribution of synapsin I and synaptophysin in hippocampal neurons developing in culture. J Neurosci 11:1617-1626.

Fletcher TL, DeCamilli P, Banker GA (1994) Synaptogenesis in hippocampal cultures: evidence indicating that axons and dendrites become competent to form synapses at different stages of neuronal development. J Neurosci 14:6695-6706.

Greengard P, Valtorta F, Czernik AJ, Benfenati F (1993) Synaptic vesicle phosphoproteins and regulation of synaptic function. Science 259:780-785

Grote E, Hao JC, Bennett MK, Kelly RB (1995) A targeting signal in VAMP regulating transport to synaptic vesicles. Cell 81:581-589.

Haas CA, DeGennaro LJ (1988) Multiple synapsin I messenger RNAs are differentially regulated during neuronal development. J Cell Biol 106:195-203.

Haas CA, DeGennaro LJ, Muller M, Hollander H (1990) Synapsin I expression in the rat retina during postnatal development. Exp Brain Res 82:25-32.

Hershey JWB (1991) Translational control in mammalian cells. Annu Rev Biochem 60:717-755.

Ip NY, Li Y, Yancopoulos GD, Lindsay RM (1993) Cultured hippocampal neurons show responses to BDNF, NT-3, and NT-4, but not NGF. J Neurosci 13:3394-3405.

Kelly RB (1993) Storage and release of neurotransmitters. Cell 72:43-53.

Knaus P, Marqueze-Pouey B, Scherer H, Betz H (1990) Synaptoporin, a novel putative channel protein of synaptic vesicles. Neuron 5:453-462.

Kraszewski K, Mundigl O, Daniell L, Verderio C, Matteoli M, De Camilli P (1995) Synaptic vesicle dynamics in living cultured hippocampal neurons visualized with CY3-conjugated antibodies directed against the lumenal domain of synaptotagmin. J Neurosci 15:4328-4342.

Leclerc N, Beesley PW, Brown I, Colonnier M, Gurd JW, Paladino T, Hawkes R (1989) Synaptophysin expression during synaptogenesis in the rat cerebellar cortex. J Comp Neurol 280:197-212.

Leube RE, Wiedenmann B, Franke WW (1989) Topogenesis and sorting of synaptophysin: synthesis of a synaptic vesicle protein from a gene transfected into nonneuroendocrine cells. Cell 59:433-446.

Leube RE, Leimer U, Grund C, Franke WW, Harth N, Wiedenmann B (1994) Sorting of synaptophysin into special vesicles in nonneuroendocrine epithelial cells. J Cell Biol 127:1585-1601.

Li J-Y, Jahn R, Dahlstrom A (1995) Rab 3a, a small GTP-binding protein, undergoes fast anterograde transport but not retrograde transport in neurons. Eur J Cell Biol 67:297-307.

Li J-Y, Edelmann L, Jahn R, Dahlstrom A (1996) Axonal transport and distribution of synaptobrevin I and II in the rat peripheral nervous system. J Neurosci 16:137-147.

Lou X, Bixby JL (1993) Coordinate and noncoordinate regulation of synaptic vesicle protein genes during embryonic development. Dev Biol 159:327-337.

Lou X, Bixby JL (1995) Patterns of presynaptic gene expression define two stages of synaptic differentiation. Mol Cell Neurosci 6:252-262.

Mahata M, Mahata SK, Fischer-Colbrie R, Winkler H (1993) Ontogenic development and distribution of mRNAs of chromogranin A and B, secretogranin II, p65, and synaptin/synaptophysin in rat brain. Dev Brain Res 76:43-58.

Marazzi G, Buckley KM (1993) Accumulation of mRNAs encoding synaptic vesicle-specific proteins precedes neurite extension during early neuronal development. Dev Dyn 197:115-124.

Matteoli M, Takei K, Perin MS, Sudhof TC, DeCamilli P (1992) Exoendocytotic recycling in developing processes of cultured hippocampal neurons. J Cell Biol 117:849-861.

Matthew W, Tsavaler L, Reichardt LF (1981) Identification of a synaptic vesicle specific membrane protein with a wide distribution in neuronal and neurosecretory tissue. J Cell Biol 9:257-269.

McMahon HT, Bolshakov VY, Janz R, Hammer RE, Siegelbaum SA, Sudhof TC (1996) Synaptophysin, a major synaptic vesicle protein, is not essential for neurotransmitter release. Proc Natl Acad Sci USA 93:4760-4764.

Melloni Jr RH, DeGennaro LJ (1994) Temporal onset of synapsin I gene expression coincides with neuronal differentiation during the development of the nervous system. J Comp Neurol 342:449-462.

Melloni Jr RH, Apostolides PJ, Hamos JE, DeGennaro LJ (1994) Dynamics of synapsin I gene expression during the establishment and restoration of functional synapses in the rat hippocampus. Neuroscience 58:683-703.

Mundigl O, DeCamilli P (1994) Formation of synaptic vesicles. Curr Opin Cell Biol 6:561-567.

Nixon RA, Cataldo AM (1995) The endosomal-lysosomal system of neurons: new roles. Trends Neurosci 18:489-496.

Papini E, Rossetto O, Cutler DF (1995) Vesicle-associated membrane protein (VAMP)/synaptobrevin-2 is associated with dense core secretory granules in PC12 neuroendocrine cells. J Biol Chem 270:1332-1336.

Perin MS, Fried VA, Mignery GA, Jahn R, Sudhof TC (1990) Phospholipid binding by a synaptic vesicle protein homologous to the regulatory region of protein kinase C. Nature 345:260-263.

Sudhof TC, Lottspeich F, Greengard P, Mehl E, Jahn R (1987a) The cDNA and derived amino acid sequence for rat and human synaptophysin. Nucleic Acids Res 15:9607.

Sudhof TC, Lottspeich F, Greengard P, Mehl E, Jahn R (1987b) Synaptophysin: a synaptic vesicle protein with four transmembrane regions and a novel cytoplasmic domain. Science 238:1142-1149.

Sudhof TC, Czernik AJ, Kao H-T, Takei K, Johnston PA, Horiuchi A, Kanazir SD, Wagner MA, Perin MS, DeCamilli P, Greengard P (1989) Synapsins: mosaics of shared and individual domains in a family of synaptic vesicle phosphoproteins. Science 245:1474-1480.

Tixier-Vidal A, Barret A, Faivre-Bauman A, Huttner W, Wiedenmann B (1992) Differential expression and subcellular localization of secretogranin II and synaptophysin during early development of mouse hypothalamic neurons in culture. Neuroscience 47:967-978.

Volknandt W, Henkel A, Zimmermann H (1988) Heterogeneous distribution of synaptophysin and protein p65 in synaptic vesicles isolated from rat cerebral cortex. Neurochem Int 12:337-345.

Walch-Solimena C, Takei K, Marek KL, Midyett K, Sudhof TC, DeCamilli P, Jahn R (1993) Synaptotagmin: a membrane constituent of neuropeptide-containing large dense-core vesicles. J Neurosci 13:3895-3903.

Wiedenmann B, Rehm H, Knierim M, Becker C-M (1988) Fractionation of synaptophysin-containing vesicles from rat brain and cultured PC12 pheochromocytoma cells. FEBS Lett 240:71-77.

Zafra F, Hengerer B, Leibrock J, Thoenen H, Lindholm D (1990) Activity dependent regulation of BDNF and NGF mRNAs in the rat hippocampus is mediated by non-NMDA glutamate receptors. EMBO J 9:3545-3550.

Zurmohle U-M, Herms J, Schlingensiepen R, Schlingensiepen K-H, Brysch W (1994) Changes of synapsin I messenger RNA expression during rat brain development. Exp Brain Res 99:17-24. 